\title{
The Unitarian Connection and Ricardo's Scientific Style
}

\author{
Sergio Cremaschi and Marcelo Dascal
}

We reply to $\mathrm{Ph}$. Depoortere's paper "On Ricardo's method: The Unitarian influence examined. Some comments on Cremaschi and Dascal's article 'Malthus and Ricardo on Economic Methodology'". Depoortere asks two questions: (1) was Ricardo's 'conversion' to Unitarianism sincere? (2) did Ricardo follow the methodology of Priestley and Belsham? His answers are that he was a "religious sceptic" and he was not an 'empiricist' like Priestley and Belsham. We reply that the sincerity of Ricardo's religious beliefs is irrelevant since we start form the evidence that he was exposed for a long time to the intellectual influence of Belsham, primarily in matters of philosophy, and to deny this would imply a negative answer to a different question, namely, did Ricardo attend Unitarian meetings over 30 years? Then we reply that Ricardo inherited Belsham's version of Newtonian methodology, which omitted the fourth rule, that is the most anti-Cartesian and anti-systematic rule, and this has little to do with empiricism.

Christophe Depoortère, in “On Ricardo's Method: The Unitarian Influence Examined," attacks two pages of our 1996 HOPE article. He asks two questions: (1) Was David Ricardo's conversion to Unitarianism sincere? and (2) Did Ricardo follow the methodology of Joseph Priestley and Thomas Belsham? His answers are that Ricardo was a religious skeptic and was not an empiricist like Priestley and Belsham. He adds that the Unitarian influence was "overrated" by Piero Sraffa.

Let us say first that Sraffa did rediscover Ricardo's Unitarianism but he underestimated its possible intellectual impact, and that we, not Sraffa, "overrated" those implications.

Second, let us remind the reader of our main point in this and three other essays (Cremaschi and Dascal 1998a, 1998b; Dascal and Cremaschi 1999). Most of Ricardo's and Thomas Malthus's methodological remarks are made in their correspondence, resulting from objections and countermoves. Since we believe that controversies contribute to intellectual progress, we set out to reconstruct their methodologies in the context of their controversy. In this way, it was possible to shed light on their different scientific styles and programs for the social sciences (see Cremaschi and Dascal 1998a).

\section{Was Ricardo a Unitarian?}

Depoortère argues that Ricardo was not a "real" Unitarian. His argument is: Ricardo was a religious skeptic $\rightarrow$ Ricardo was an atheist $\rightarrow$ Ricardo's conversion to the most liberal of the available religious options was a matter of convenience.

Reply: We are not concerned with Ricardo's sincerity, but with his association for many years with the proponents of peculiar philosophical views. Depoortère's argument, if sound, would be irrelevant. But it is also full of non sequiturs.

First, is there any evidence that Ricardo was faking his commitment to Unitarianism?

Second, the speech of Ricardo's that Depoortère mentions was in support of a petition whose "prime mover" was Robert Aspland, one of the two main Unitarian divines of the day!

Third, Priestley and Belsham, as well as Locke before them, had been using the same skeptical argument used by Ricardo, namely, that no one can judge the truth or falsity of religious beliefs on behalf of others.

Fourth, if Ricardo was a religious skeptic, this does not mean that he was a crypto-atheist. Ricardo was defending limited skepticism, or he was claiming that rational arguments are not decisive in matters of religious belief, which is much less than agnosticism or atheism. His admiration for Pierre Bayle would be a challenge for us only if Bayle were still assumed to be some kind of crypto-atheist, instead of a proponent of Christianity without theology, not far from the tradition of Socinianism, to which also the English Unitarians belong. 
And finally, the difficulty in providing any solution to the problem of evil is precisely the point where the Unitarians converged with the Christian skeptic Bayle. According to Belsham (1826, 37), "When we consider the divine dispensations in detail, we shall immediately discover that they are far beyond the reach of human sagacity," and he believed that the fact "that evil, natural and moral, is unavoidable in the works of God, is a problem of very difficult solution" (37). We face an "inexplicable difficulty" that the "wisdom of man in vain attempts to unravel and explore" (37). This sounds as skeptical as Bayle and as Ricardo's comment in his letter to James Mill. Shall we infer from the above statements that Belsham had ceased to be the leading Unitarian divine?

\section{Did Ricardo “Follow” Belsham's Methodology?}

Question 2 is not the right kind of question. What we contend is that neither Malthus nor Ricardo's ever "applied" any ready-made method, and that - in spite of differences and misunderstandingsthe main influence on Ricardo's theorizing came precisely from Malthus. Ricardo did not "follow" Belsham's and Priestley's method, but no economist ever followed anybody's method! The right formulation of question 2 would be, What was the methodological legacy of Priestley and Bentham, and how relevant is it to our understanding of Ricardo?

Depoortère's answer is that Ricardo's methodology could not have been influenced by Belsham because Belsham was a follower of David Hartley's theory of knowledge; Hartley's theory, it may be recalled, accepted hypotheses as useful heuristic devices, whereas Ricardo believed his principles to be "natural laws." Depoortère adds that Belsham, in his account of Newton's rules, omitted the fourth rule (induction yields laws that cannot be "evaded by hypotheses") on purpose.

Reply: We ourselves pointed out that Belsham omitted the fourth rule on purpose. We may add that Priestley himself, curiously enough, mentioned only the first two rules (Priestley [1777] 1972, 221 and 229).

Depoortère's further claim is that the reason for such a deliberate omission of the fourth rule is a belief in the heuristic fruitfulness of hypotheses.

Reply: In his controversy with Thomas Reid and Richard Price, Priestley did defend Hartley's psychology as well as his materialism and necessitarianism, but he had his own methodological and epistemological doctrines - a kind of Baconian Newtonianism. Priestley's claims were that those "hypotheses" should be accepted that better account for the "appearances"; "superficial appearances" should be discarded, and only "real appearances" should be taken into account; multiplication of causal powers is unnecessary; the first two Newtonian rules are the important ones; scientific "laws" may be known with a sufficient amount of certainty without any certainty about the underlying ultimate "causes"; "substances" are unknowable, and only properties can be grasped. We showed that these are also the doctrines that Belsham popularized. The issue is not whether Priestley and Belsham were followers of Hartley's associationism; what matters is what claims they argued for on each level, namely, psychology, the theory of knowledge, and methodology. Actually, they defended limited skepticism in epistemology, and — oddly enough — an aprioristic methodology that favored artificial scientific terminology, monocausality, idealization, and general laws.

Depoortère's final step is that such a vindication of hypotheses contrasts with Ricardo's belief in the nonhypothetical character of "principles."

Reply: We argued that Ricardo is far from univocal on the status of theoretical principles. Nevertheless he believed that such principles are hypotheses in the Newtonian sense, and his comparison betweeen his laws and the principle of gravitation has precisely this implication.

There is external contextual evidence of Ricardo's exposure to their views; besides, there is internal textual evidence such as similarity of language and claims between Ricardo and Priestley and Belsham; thus, looking at their writings as sources of clarification for Ricardo's methodological remarks is quite reasonable.

We did not claim that Ricardo had a method that he applied to economic theory. On the contrary, we argued that methodology is just one of several assets used by economists in their 
controversies (see Dascal and Cremaschi 1999). Nonetheless, the meaning of their comments cannot be decided by a priori definitions, but it is a matter of patient reconstruction and interpretation.

It turns out, then, that Depoortère disagrees from our views on the Unitarian legacy in Ricardo's methodology simply because he disagrees from our reconstruction of Priestley's and Belsham's ideas on method.

\section{References}

Belsham, T. 1826. Imperfection of Human Knowledge. Part the Second. In vol. 1 of Discourses, Doctrinal and Practical. London: Hunter.

Cremaschi, S., and M. Dascal. 1996. Malthus and Ricardo on Economic Methodology. HOPE 28.3:475-511.

1998a. Malthus and Ricardo: Two Styles for Economic Theory. Science in Context 11.2:229-54.

1998b. Persuasion and Argument in the Malthus-Ricardo Correspondence. In Research in the History of Economic Thought and Methodology, edited by W. J. Samuels and J. E. Biddle, 1-63. Stamford, Conn.: JAI Press.

Dascal, M., and S. Cremaschi. 1999. The Malthus-Ricardo Correspondence: Sequential Structure, Argumentative Patterns, and Rationality. Journal of Pragmatics 31: 1129-72.

Priestley, J. [1777] 1972. Disquisitions relating to Matter and Spirit. In vol. 3 of The Theological and Miscellaneous Works, edited by John Towill Rutt. New York: Kraus. 